\title{
Decision Support System for Accepting Social Assistance for the Program
}

\section{Keluarga Harapan (PKH)}

\author{
Aji Pangestu ${ }^{1, *}$ \\ Sistem Informasi, Universitas Amikom Purwokerto, Indonesia \\ ${ }^{1}$ ajipangst@gmail.com* \\ * corresponding author
}

(Received: August 5, 2021 Revised: October 19, 2021 Accepted: December 6, 2021, Available online: January 29, 2022)

\begin{abstract}
Cibangkong Village is one of the villages in Pekuncen District, Banyumas Regency. The number of recipients of PKH cards (Program Keluarga Harapan) is 253 families, data on KPM (Beneficiary Families) prospective recipients of BPNT (Non-Cash Food Assistance) are 278 families, and data for recipients of BLT (Direct Cash Assistance) village funds are 217 people (source Cibangkong Village in 2021). With so many recipients of this assistance, village officials encountered several obstacles, one of which was that the recipients were not eligible to receive assistance. This needs to be handled, one of which is by creating a Decision Support System that can assist village officials in overcoming these problems. Decision Support System (DSS) is a system that can assist a person in making accurate and targeted decisions. This study aims to produce a Decision Support System for receiving social assistance from the Family Hope Program (PKH) in Cibangkong village. This research uses the Multi Attribute Utility Theory (MAUT) method. The result of this research is that the making of a decision support system for receiving social assistance for the Family Hope Program (PHK) in Cibangkong village can be used as a tool by the Cibangkong village apparatus to consider the feasibility of prospective recipients of PKH social assistance. The criteria used in the Decision Support System for receiving social assistance from the Family Hope Program (PHK) in Cibangkong village are 12, namely income, savings, consuming meat, milk and chicken, ability to pay for treatment, education of the head of the family, building area, type of floor, house walls, latrines/WC, lighting sources, drinking water sources, and cooking fuel.
\end{abstract}

Keywords: Decision Support System; Family Hope Program (PKH); Multi Attribute Utility Theory (MAUT)

\section{Introduction}

The Family Hope Program (PKH) is a program that provides cash assistance to Very Poor Households (RTSM) [1]. In return, the RTSM is required to meet the requirements related to efforts to improve the quality of human resources (HR), namely education and health. The main objective of PKH is to reduce poverty and improve the quality of human resources, especially for the poor. This goal is also an effort to accelerate the achievement of the MDGs targets [2].

Several problems related to determining the acceptance of social assistance programs in Cibangkong village are still carried out manually, namely by using old data available at the village office [3]. Data collection is carried out 1-2 times every year. This makes the data in the village office less valid and effective, causing some beneficiaries to be off target [4]. Data collection is done by collecting KK (Family Card) which is used to see the number of family dependents and collecting salary slips for residents who work as PNS (Civil Employees), while for residents who work as farmers and entrepreneurs report their income using instant reporting to the village government [5].

To determine the eligibility of recipients of social assistance programs in Cibangkong village, one solution that can be used is to use a computerized system that can produce accurate data and in accordance with existing criteria [6]. This system will use a website platform. For this reason, researchers try to help these problems by developing a 
A. Pangestu / IJIIS Vol. 5 No. 12022 , pp. 38-46

Decision Support System [7]. The creation of a website-based Decision Support System is a good alternative by prioritizing effectiveness and efficiency in receiving PKH assistance [8].

The purpose of this decision support system is to determine eligible recipients for PKH assistance using the Multi Attribute Utility Theory (MAUT) method [9]. The end result is a ranking order of alternative evaluations that describes the choices of decision makers at the Cibangkong village office. The Decision Support System created is only used for data collection in Cibangkong village.

\section{Method}

\section{Decision Support System}

Decision Support System is an interactive computer-based system that can assist decision makers in using data and models to solve unstructured problems [10]. Decision Support System (DSS) is a system that is used as a problem solving tool to assist decision makers (managers) in making decisions, but not to replace the manager's capacity, only to provide considerations [11].

\section{Multi Attribute Utility Theory (MAUT) Method}

The Multi-Attribute Utility Theory (MAUT) method is a quantitative comparison method that usually combines various measures of costs, risks, and benefits [12]. Each existing standard has several alternatives that can provide solutions. To find an alternative approach that is close to the user's expectations to identify it, multiplication is carried out for a predetermined priority ratio. In order to use the best and closest results from these alternatives as a solution [13].

OFF is used to convert multiple interests to values in the range $0-1$, where 0 represents the worst choice and 1 represents the best choice. This allows direct comparison of various sizes [14]. For the calculation of the entire evaluation value, several equations can be used to define, the formula is as follows:

$$
V(x)=\sum_{i=1}^{n} \operatorname{WiVi}(x)
$$

Where $\operatorname{Vi}(\mathrm{x})$ is the evaluation value of an $\mathrm{i}$-th object and Wi is a weight that determines the value of how important the $\mathrm{i}$-th element is to other elements [14]. While $\mathrm{n}$ is the number of elements. The total of the weights is 1.

$$
\sum_{i=1}^{n} W i=1
$$

For each dimension, the evaluation value $\mathrm{Vi}(\mathrm{x})$ is defined as the sum of the relevant attributes.

$$
\operatorname{Vi}(x)=\sum_{e=A i} \text { Wai.Vai }(I(a))
$$

Description :

$\mathrm{V}(\mathrm{x})=$ evaluation value

$\mathrm{n}=$ Number of elements/criteria

$\mathrm{i}=$ Total weight is 1

$\mathrm{Ai}=$ set of all relevant attributes

$\operatorname{Vai}(1(\mathrm{a}))=$ evaluation of the actual level

Wai $=$ weight that determines the impact of attribute evaluation on dimension

$\mathrm{vi}=$ the overall value of the alternative choice of a criterion 
$\mathrm{a}=$ criteria

In summary, the steps in the MAUT method are as follows:

1. Break a decision into different dimensions.

2. Determine the relative weights on each dimension

3. List of all alternatives

4. Calculates the utility value of matrix normalization for each alternative according to its attributes.

$$
U(x)=\frac{(x-X i)}{x i^{+}-x i}
$$

Description :

$\mathrm{U}(\mathrm{x})=$ Normalized alternative weight

$\mathrm{xi}+=$ minimum criterion value (worst weight)

$\mathrm{xi}^{-}=$maximum criterion value (best weight)

$\mathrm{x}=$ Alternative weight

5. Multiply utility by weight to find the value of each alternative

\section{Results and Discussion}

Determination of prospective beneficiaries of PKH assistance in Cibangkong village using the MAUT method with the following stages:

\section{Determining Alternative}

In this study, the alternative used is the data of the residents of Cibangkong village which has been data by Cibangkong village officials, as follows:

Table 1. Citizen Alternative Data

\begin{tabular}{cll}
\hline No & Resident's Name & Address \\
\hline 1 & Aswen & RT 04/RW 02 \\
\hline 2 & Kamsini & RT 04/RW 02 \\
\hline 3 & Waryati & RT 03/RW 02 \\
\hline 4 & Ratna Pradipta Sari & RT 03/RW 02 \\
\hline 5 & Warsiyem & RT 02/RW 02 \\
\hline 6 & Nikem & RT 03/RW 02 \\
\hline 7 & Nilem & RT 03/RW 02 \\
\hline 8 & Sutinah & RT 06/RW 02 \\
\hline 9 & Tijah & RT 04/RW 02 \\
\hline 10 & Feri Yulianti & RT 02/RW 02 \\
\hline
\end{tabular}

\section{Determining Criteria Components}

This study uses the following criteria components: economic conditions, social conditions and building conditions.

\section{Determining Criteria Weight}

Based on the criteria that have been determined, then determine the weight of each criterion that has been determined. The weights for each criterion were obtained based on the results of discussions with Cibangkong village officials as follows:

Table 2. Criteria Component Weight

\begin{tabular}{ccc}
\hline No & Criteria Component & Weight \\
\hline 1 & Economy & 0,1 \\
\hline 2 & Social & 0,3 \\
\hline 3 & Building & 0,6 \\
\hline
\end{tabular}


A. Pangestu / IJIIS Vol. 5 No. 1 2022, pp. 38-46

\section{Determining the Priority of Sub-criteria Against Each Criterion}

\section{Components of Economic Condition Criteria}

The criteria for economic conditions have sub-criteria, namely: income and savings.

Table 3. Sub-Criteria Economic Condition

\begin{tabular}{cllll}
\hline No & Variable & Criteria Name & Sub Criteria & $\begin{array}{l}\text { Sub Criteria Weight } \\
\text { Value }\end{array}$ \\
\hline 1 & $\mathrm{C} 1$ & Income & $>\mathrm{Rp} .600 .000$ & 1 \\
\cline { 3 - 5 } & & Savp. 600.000 & 2 \\
\hline 2 & $\mathrm{C} 2$ & Savings & Own & 1 \\
\cline { 3 - 4 } & & & Do not own & 2 \\
\hline
\end{tabular}

\section{Components of Social Condition Criteria}

The criteria for social conditions have sub-criteria, namely: consuming meat, milk, and chicken, being able to pay for treatment, and education of the head of the family.

Table 4. Social Condition Sub Criteria

\begin{tabular}{|c|c|c|c|c|c|}
\hline No & Variable & Criteria Name & Sub Criteria & $\begin{array}{ll}\text { Sub } & \text { Criteria } \\
\text { Value } & \\
\end{array}$ & Weight \\
\hline \multirow[t]{3}{*}{1} & \multirow[t]{3}{*}{$\mathrm{C} 3$} & \multirow{3}{*}{$\begin{array}{l}\text { Consuming meat, milk and } \\
\text { chicken }\end{array}$} & $1 \mathrm{x}$ a week & 1 & \\
\hline & & & $1 \mathrm{x}$ a month & 2 & \\
\hline & & & $1 \mathrm{x}$ a year & 3 & \\
\hline \multirow[t]{2}{*}{2} & \multirow[t]{2}{*}{$\mathrm{C} 4$} & \multirow[t]{2}{*}{ Ability to pay for treatment } & Capable & 1 & \\
\hline & & & Unable & 2 & \\
\hline \multirow[t]{2}{*}{3} & \multirow[t]{2}{*}{$\mathrm{C} 5$} & \multirow[t]{2}{*}{ Family head education } & $\begin{array}{l}\text { finished } \\
\text { elementary school }\end{array}$ & 1 & \\
\hline & & & $\begin{array}{l}\text { Not completed in } \\
\text { primary school }\end{array}$ & 2 & \\
\hline
\end{tabular}

\section{Components of Building Condition Criteria}

The criteria for building conditions have sub-criteria, namely: building area, type of floor, house walls, latrines/WC, lighting sources, drinking water sources, cooking fuel.

Table 5. Sub Criteria for Building Conditions

\begin{tabular}{|c|c|c|c|c|}
\hline No & Variable & Criteria Name & Sub Criteria & Sub Criteria Weight Value \\
\hline \multirow[t]{2}{*}{1} & \multirow[t]{2}{*}{ C6 } & \multirow[t]{2}{*}{ Building area } & $>8 \mathrm{~m}^{2}$ & 1 \\
\hline & & & $<8 \mathrm{~m}^{2}$ & 2 \\
\hline \multirow[t]{3}{*}{2} & \multirow[t]{3}{*}{$\mathrm{C} 7$} & \multirow[t]{3}{*}{ Floor type } & Ceramic & 1 \\
\hline & & & Cement & 2 \\
\hline & & & Land & 3 \\
\hline \multirow[t]{2}{*}{3} & \multirow[t]{2}{*}{$\mathrm{C} 8$} & \multirow[t]{2}{*}{ House wall } & Brick & 1 \\
\hline & & & Wood & 2 \\
\hline \multirow[t]{2}{*}{4} & \multirow[t]{2}{*}{ C9 } & \multirow[t]{2}{*}{ Toilet } & Own & 1 \\
\hline & & & Do not own & 2 \\
\hline \multirow[t]{2}{*}{5} & \multirow[t]{2}{*}{$\mathrm{C} 10$} & \multirow[t]{2}{*}{ Lighting } & Using electricity & 1 \\
\hline & & & Does not use electricity & 2 \\
\hline \multirow[t]{2}{*}{6} & \multirow[t]{2}{*}{ C11 } & \multirow[t]{2}{*}{ Source of water } & Well & 1 \\
\hline & & & Unfiltered water & 2 \\
\hline \multirow[t]{3}{*}{7} & \multirow[t]{3}{*}{$\mathrm{C} 12$} & \multirow[t]{3}{*}{ Cooking fuel } & Gas & 1 \\
\hline & & & Oil & 2 \\
\hline & & & Firewood & 3 \\
\hline
\end{tabular}

\section{Determining Alternative Data}

The alternative data used is data that has been recorded by Cibangkong village officials based on the number of files received. 
A. Pangestu / IJIIS Vol. 5 No. 1 2022, pp. 38-46

Table 6. Alternative Citizen Rating Score

\begin{tabular}{clcccccccccccc}
\hline No & Citizen Data & C1 & C2 & C3 & C4 & C5 & C6 & C7 & C8 & C9 & C10 & C11 & C12 \\
\hline 1 & Aswen & 2 & 1 & 2 & 2 & 2 & 2 & 1 & 2 & 1 & 1 & 2 & 2 \\
\hline 2 & Kamsini & 1 & 1 & 2 & 2 & 1 & 1 & 2 & 2 & 1 & 1 & 2 & 1 \\
\hline 3 & Waryati & 2 & 1 & 2 & 2 & 1 & 1 & 1 & 1 & 1 & 1 & 2 & 1 \\
\hline 4 & Ratna P. S. & 1 & 1 & 2 & 2 & 1 & 1 & 2 & 2 & 2 & 1 & 2 & 1 \\
\hline 5 & Warsiyem & 2 & 1 & 2 & 2 & 2 & 1 & 2 & 2 & 2 & 1 & 2 & 3 \\
\hline 6 & Nikem & 1 & 1 & 2 & 2 & 1 & 1 & 2 & 1 & 2 & 1 & 2 & 1 \\
\hline 7 & Nilem & 2 & 1 & 2 & 2 & 2 & 1 & 2 & 2 & 2 & 1 & 2 & 3 \\
\hline 8 & Sutinah & 1 & 1 & 2 & 2 & 1 & 1 & 1 & 1 & 1 & 1 & 2 & 1 \\
\hline 9 & Tijah & 2 & 1 & 2 & 2 & 2 & 1 & 2 & 2 & 2 & 1 & 2 & 3 \\
\hline 10 & Feri Yulianti & 1 & 1 & 2 & 2 & 1 & 1 & 1 & 2 & 1 & 1 & 2 & 1 \\
\hline
\end{tabular}

\section{Determining the Normalization Value of the Matrix}

After determining the criteria and alternatives from the residents of Cibangkong village, the next step is to create a normalized matrix. The following is a normalized matrix:

Table 7. Normalization of Citizen Alternative Matrix

\begin{tabular}{|c|c|c|c|c|c|c|c|c|c|c|c|c|c|}
\hline No & Citizen Data & C1 & $\mathrm{C2}$ & $\mathrm{C3}$ & $\mathrm{C4}$ & $\mathrm{C5}$ & C6 & C7 & $\mathrm{C8}$ & C9 & $\mathrm{C10}$ & C11 & $\mathrm{C12}$ \\
\hline 1 & Aswen & 1 & 0 & 0,5 & 1 & 1 & 1 & 0 & 1 & 0 & 0 & 1 & 0,5 \\
\hline 2 & Kamsini & 0 & 0 & 0,5 & 1 & 0 & 0 & 0,5 & 1 & 0 & 0 & 1 & 0 \\
\hline 3 & Waryati & 1 & 0 & 0,5 & 1 & 0 & 0 & 0 & 0 & 0 & 0 & 1 & 0 \\
\hline 4 & Ratna P. S. & 0 & 0 & 0,5 & 1 & 0 & 0 & 0,5 & 1 & 1 & 0 & 1 & 0 \\
\hline 5 & Warsiyem & 1 & 0 & 0,5 & 1 & 1 & 0 & 0,5 & 1 & 1 & 0 & 1 & 1 \\
\hline 6 & Nikem & 0 & 0 & 0,5 & 1 & 0 & 0 & 0,5 & 0 & 1 & 0 & 1 & 0 \\
\hline 7 & Nilem & 1 & 0 & 0,5 & 1 & 1 & 0 & 0,5 & 1 & 1 & 0 & 1 & 1 \\
\hline 8 & Sutinah & 0 & 0 & 0,5 & 1 & 0 & 0 & 0 & 0 & 0 & 0 & 1 & 0 \\
\hline 9 & Tijah & 1 & 0 & 0,5 & 1 & 1 & 0 & 0,5 & 1 & 1 & 0 & 1 & 1 \\
\hline 10 & Feri Yulianti & 0 & 0 & 0,5 & 1 & 0 & 0 & 0 & 1 & 0 & 0 & 1 & 0 \\
\hline
\end{tabular}

\section{Ranking Results}

From the results of the matrix multiplication, we can determine the ranking of the recipients of PKH assistance. The following is a ranking of the results of each alternative:

Table 8. Citizen Alternative Ranking Results

\begin{tabular}{clcc}
\hline No & Citizen Alternative & Results & Ranking \\
\hline 1 & Warsiyem & 0,7 & 1 \\
\hline 2 & Nilem & 0,7 & 2 \\
\hline 3 & Tijah & 0,7 & 3 \\
\hline 4 & Aswen & 0,65 & 4 \\
\hline 5 & Kamsini & 0,45 & 5 \\
\hline 6 & Ratna P. S. & 0,45 & 6 \\
\hline 7 & Nikem & 0,35 & 7 \\
\hline 8 & Feri Yulianti & 0,35 & 8 \\
\hline 9 & Waryati & 0,3 & 9 \\
\hline 10 & Sutinah & 0,25 & 10 \\
\hline
\end{tabular}


A. Pangestu / IJIIS Vol. 5 No. 1 2022, pp. 38-46

\section{Alternative Data Input on Website}
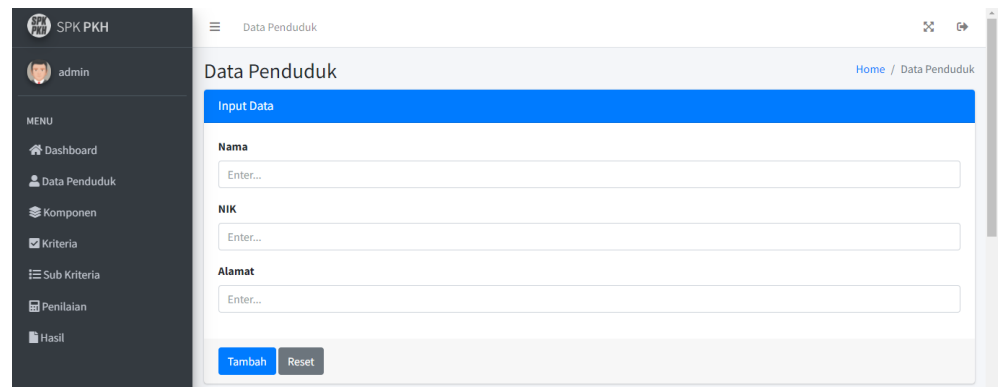

Figure. 1. Population Data Menu Display

Figure 1. displays the population data menu. Here the admin can input the residents of the Cibangkong village by filling in the name, NIK, and address fields and then clicking add.
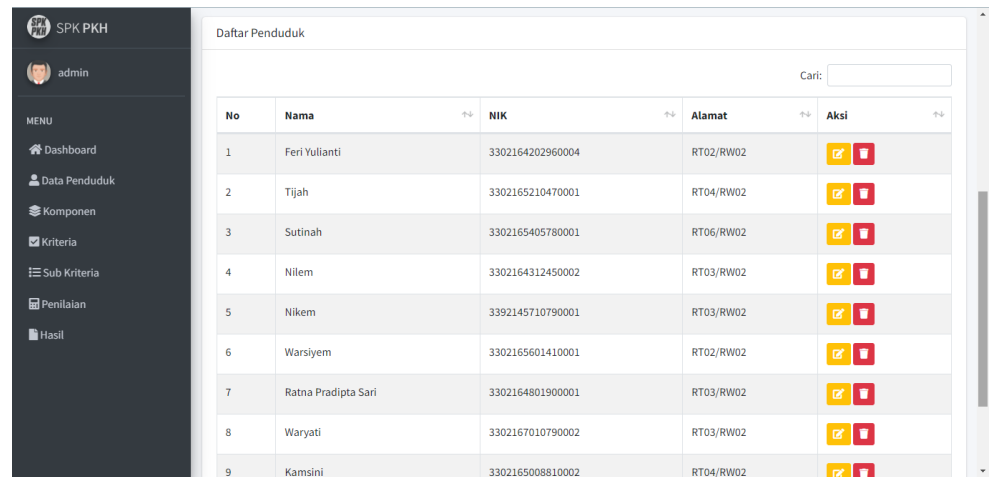

Figure. 2. Display of Population Data List

Figure 2. shows a list of residents on the population data menu. Here the admin can change or delete resident data.

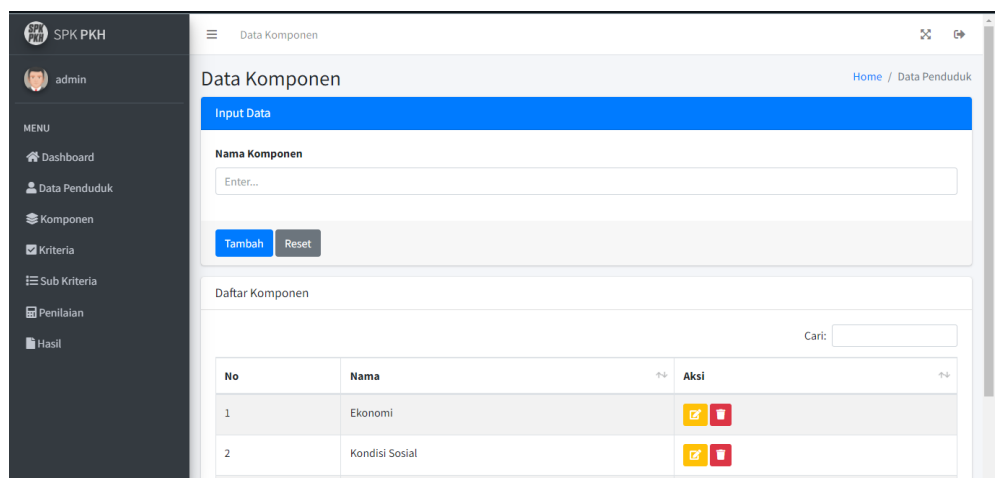

Figure. 3. Criteria Component Data Menu Display

Figure 3. displays the component menu. Here the admin can input the beneficiary component by filling in the component name column and then clicking add. 
A. Pangestu / IJIIS Vol. 5 No. 1 2022, pp. 38-46

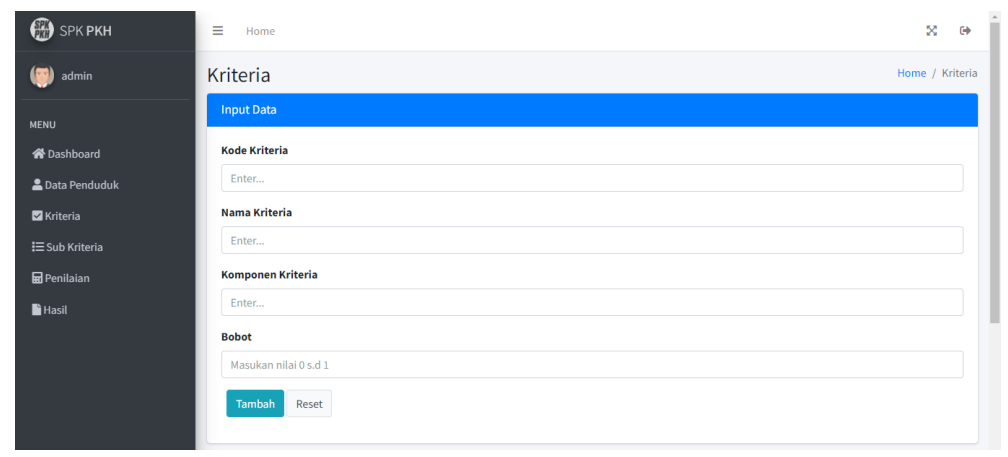

Figure. 4. Criteria Menu Display

Figure 4. displays the criteria menu. Here the admin can input the criteria for the beneficiary by filling in the criteria code column, criteria name, criteria component, and weight and then click add.

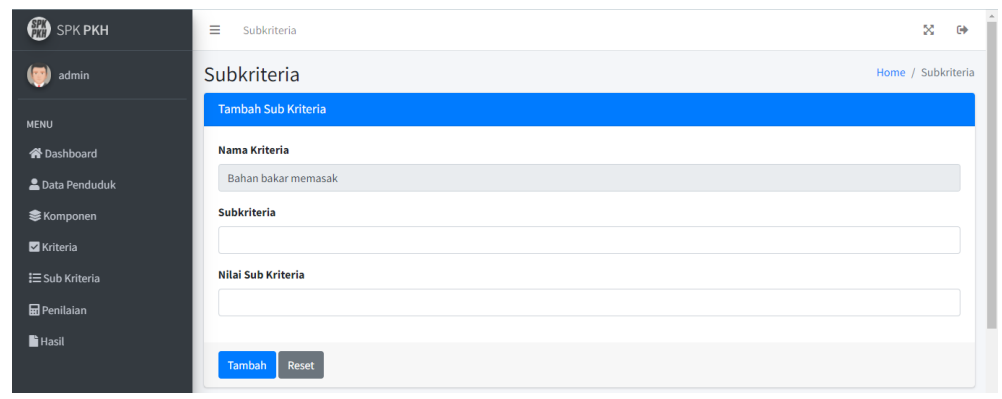

Figure 5. Sub-Criteria Menu Display

Figure 5. shows the sub criteria menu. Here the admin can add sub-criteria to the list of existing criteria.

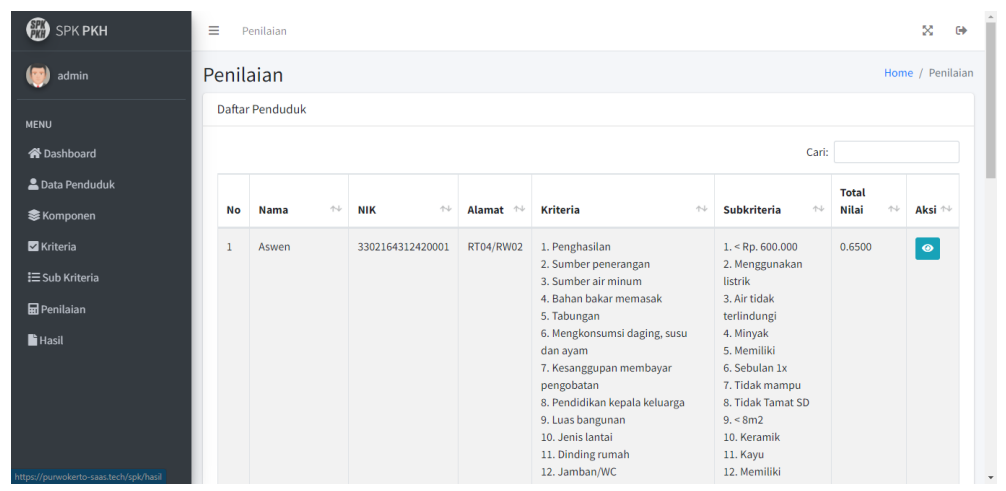

Figure 6. Rating Menu Display

Figure 6. displays the assessment menu. Here the admin performs the SPK calculation process to determine the results of which villagers deserve PKH social assistance. 
A. Pangestu / IJIIS Vol. 5 No. 12022 , pp. 38-46

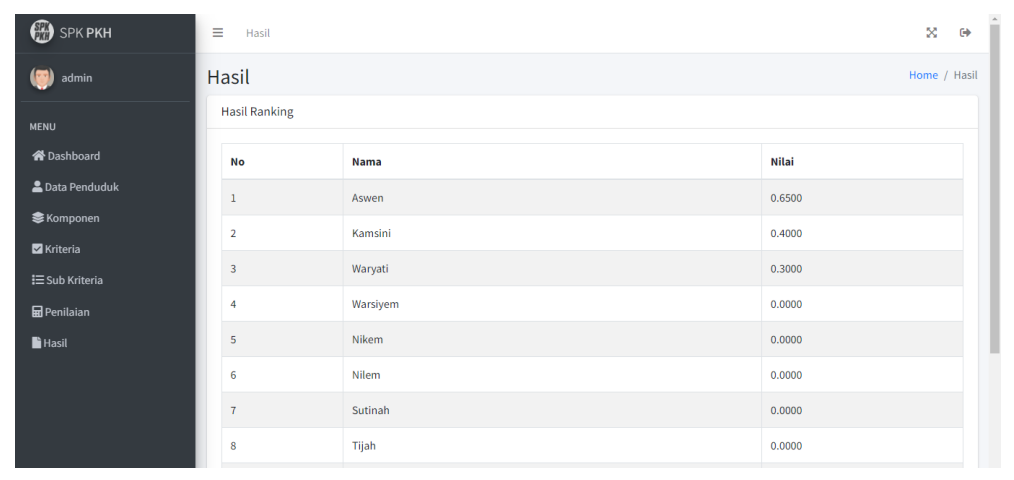

Figure 7. Display of Ranking Results

Figure 7. displays the results menu. Here the admin can see the results of the SPK calculation process according to the ranking or the largest value obtained by its citizens.

\section{Conclusion}

Making a Decision Support System for receiving social assistance from the Family Hope Program (PHK) in Cibangkong village can be used as a tool by Cibangkong village officials to consider the eligibility of candidates for PKH social assistance. The criteria used in the Decision Support System for receiving social assistance from the Family Hope Program (PHK) in Cibangkong village are 12, namely income, savings, consuming meat, milk and chicken, ability to pay for treatment, education of the head of the family, building area, type of floor, house walls , latrines/WC, lighting sources, drinking water sources, and cooking fuel.

\section{Reference}

[1] H. Bidgoli, “Integration of Technologies: An Ultimate Decision-Making Aid,” Ind. Manag. Data Syst., vol. 93, no. 1, pp. 10-17, Jan. 1993, doi: 10.1108/02635579310025679.

[2] G. I. Zekos, "MNEs, globalisation and digital economy: legal and economic aspects,” Manag. Law, vol. 45, no. 1/2, pp. 1-296, Jan. 2003, doi: 10.1108/03090550310770875.

[3] A. J. Greco and J. T. Hogue, "Developing Marketing Decision Support Systems in Consumer Goods Firms," J. Consum. Mark., vol. 7, no. 1, pp. 55-64, Jan. 1990, doi: 10.1108/EUM0000000002570.

[4] G. H. van Bruggen, A. Smidts, and B. Wierenga, "The powerful triangle of marketing data, managerial judgment, and marketing management support systems," Eur. J. Mark., vol. 35, no. 7/8, pp. 796-816, Jan. 2001, doi: 10.1108/EUM0000000005726.

[5] K. L. Hansen, D. M. Gann, and S. Groak, "Information technology decision support and business process change in the USA,” Eng. Constr. Archit. Manag., vol. 5, no. 2, pp. 115-126, Jan. 1998, doi: 10.1108/eb021066.

[6] G. Shankaranarayanan and B. Zhu, "Enhancing decision-making with data quality metadata,” J. Syst. Inf. Technol., vol. 23, no. 2, pp. 199-217, Jan. 2021, doi: 10.1108/JSIT-08-2020-0153.

[7] H. N. Wilson and M. H. B. McDonald, "An evaluation of styles of IT support for marketing planning," Eur. J. Mark., vol. 35, no. 7/8, pp. 815-842, Jan. 2001, doi: 10.1108/EUM0000000005727.

[8] B. Doolin, “A framework for interpreting decision support system use in organisations,” J. Syst. Inf. Technol., vol. 1, no. 2, pp. 1-22, Jan. 1997, doi: 10.1108/13287269780000735.

[9] F. M. Kasie, G. Bright, and A. Walker, "Decision support systems in manufacturing: a survey and future trends," J. Model. Manag., vol. 12, no. 3, pp. 432-454, Jan. 2017, doi: 10.1108/JM2-02-2016-0015.

[10] A. J. Greco and J. T. Hogue, “Developing Marketing Decision Support Systems,” J. Bus. Ind. Mark., vol. 5, no. 2, pp. 27-36, Jan. 1990, doi: 10.1108/EUM0000000002742.

[11]Z. Huang and Y. Liang, "Research of data mining and web technology in university discipline construction decision support system based on MVC model," Libr. Hi Tech, vol. 38, no. 3, pp. 610-624, Jan. 2020, doi: 10.1108/LHT-09-2018-0131.

[12] G. Leslie, "Decision support systems: learning to apply computers," Aslib Proc., vol. 38, no. 9, pp. 275-283, Jan. 1986, doi: $10.1108 / \mathrm{eb060048.}$ 


\section{A. Pangestu / IJIIS Vol. 5 No. 12022 , pp. 38-46}

[13] S. Gasson and K. M. Shelfer, "IT-based knowledge management to support organizational learning," Inf. Technol. People, vol. 20, no. 4, pp. 376-399, Jan. 2007, doi: 10.1108/09593840710839806.

[14]E. M. Saniga, "Decision Support and Statistical Quality Control,” Int. J. Qual. Reliab. Manag., vol. 10, no. 2, Jan. 1993, doi: $10.1108 / 02656719310027948$.

[15] N. N. Nagarur and J. Kaewplang, “An object-oriented decision support system for maintenance management,” J. Qual. Maint. Eng., vol. 5, no. 3, pp. 248-257, Jan. 1999, doi: 10.1108/13552519910282719.

[16] J. Rohacs, I. Jankovics, and D. Rohacs, "Less-skilled pilot decision support,” Aircr. Eng. Aerosp. Technol., vol. 91, no. 5, pp. 790-802, Jan. 2019, doi: 10.1108/AEAT-12-2017-0269.

[17] K. H. Spencer Pickett, "Diary of a control freak: the manager's guide to internal control,” Manag. Audit. J., vol. 13, no. 4/5, pp. 210-332, Jan. 1998, doi: 10.1108/02686909810216291.

[18] G. Feldman, H. Shah, C. Chapman, E. A. Pärn, and D. J. Edwards, "A systematic approach for enterprise systems upgrade decision-making,” J. Eng. Des. Technol., vol. 15, no. 6, pp. 778-802, Jan. 2017, doi: 10.1108/JEDT-08-2017-0076.

[19] Y. Duan and R. Kinman, “Small manufacturing businesses: meeting decision support needs,” J. Small Bus. Enterp. Dev., vol. 7, no. 3, pp. 272-284, Jan. 2000, doi: 10.1108/EUM0000000006845.

[20] K. H. Spencer Pickett, “The manager's guide to internal control: diary of a control freak,” Manag. Decis., vol. 37, no. 2, pp. 93-215, Jan. 1999, doi: 10.1108/00251749910252076. 